$\begin{gathered}\text { Украӥнська } \\ \text { мова } \\ \text { Ukrainian } \\ \text { language }\end{gathered}$
ВЛАСНЕ ВЕСІЛЬНІ ОБРЯДОТЕРМІНИ
У БУКОВИНСЬКИХ ГОВІРКАХ.
Юлія РУСНАК,
ВДНЗ України «Буковинський державний
медичний університет», Чернівці (Україна)
јulijarusnak@rambler.ru
WEDDING RITE TЕRМS ОF ВUКОVINIAN DIALECT
Yulia RUSNAK,
Higher State Educational Establishment of Ukraine
«Bukovinian State Medical University», Chernivtsi (Ukraine)
Researcher ID : S-8544-2016
ORCID 0000-0001-9941-4411

ISSN: 2411-6181(on-line); ISSN: 2311-9896 (print)

Current issues of social studies and history of medicine. Joint

Ukrainian-Romanian scientific journal, 2017, №:1(13), P. 30-32

UDK 811.161. 2'282.3(477.85)'373

DOI 10.24061/2411-6181.1.2017.6

Руснак Ю. Свадебные обрядотермины в буковинских говорах. Свадебное действо составляет единство предсвадебного, свадебного и послесвадебного этапов. В статье проанализировано свадебную обрядовую терминологию в буковинских говорах. Исследование соответствует этнолингвистическому аспекту языкознания, поскольку лексика семейной обрядности в говорах составляет слой лексем с так называемым „культурным компонентом", то есть в них отражено реалии культуры народа.

Ключевые слова: свадебный обряд, буковинские говоры, номинатвный ряд, духовная культура, номинация.

Formulation of the problem. Wedding is the beginning of the new family. It is central solemn event in everyone's life, the key of procreation. „Wedding ceremonies are traditions, which are enshrined by society, customs, that mark the marriage, the birth of a new family" . Wedding shows the unity of pre-wedding, wedding and post-wedding stages.

The analysis of recent researches and publications about solution of the problem. The vocabulary of wedding rite is enough studied in Ukrainian linguistics. The nomination of wedding ceremony of hutsul dialects is studied by $\mathrm{M}$. Bihusyak, serednonaddnipryanski - by N. Hrozovska, stepovi by V. Drobotenko, shidnoslobozhanski - by I. Mahrytska, stepovi - by P. Romaniuk, boykivski - by N.Hibeba, podilskobukovynsko-naddnistrianski - by $\mathrm{O}$. Zhvava, wedding literary language vocabulary is analyzed by V. Shevchenko. Systematic study of vocabulary marriage ceremony on the materials of Bukovinian dialects is not carried out, but partly lingual features of wedding name of the region are discussed in articles of V. Prokopenko and N. Huyvanyuk.

The purpose of the article is to analyze the actual wedding rite terminology in Bukovinian dialects. Research deals with the ethnolinguistic aspects of linguistics, language dialects in family rites represent the layer, which is called „cultural component", it reflects the realities of the culture and people. According to N.Huyvanyuk, ethnolinguistic aspect is an important component of the system of dialect vocabulary description $^{2}$.

Representing of the main material. The unit of descriptions is the total nomination to designate one denotation. The wedding rite terminology of Bukovinian dialects is represented in „names of bride's gathering”, ,names of pilgrimage blessing”, „names of pre-main events“, ,names of the church and civil marriage”, „common names of wedding entertainment”, , names of common eating”, „, names of making presents", „,names of ancient rite”, „,names of bride's covering”, „final rite names", „names to describe the departure of the bride".

Dressing of the bride is the important ritual. In Bukovinian dialects there are such nominations with the meaning ,to wear" od'a'gaty: zby'ratysy(sa), uby'raty(sa), obr'ad'zhaty, ud'i'gaty, ud'i'vaty, uby'raty u 'vishyte ub'ran'e. Ukrainian dictionary records 12 meanings of the word ,wear" zbyraty, but the main meaning of this word „to dress" odyagaty is absent ${ }^{3}$.

One of the essential events is rite of blessing the wedding. Brides ask the forgiveness of sins on the eve of church rite, but it can occur before the wedding or just before the church rite. This event is entitled: blagoslo'ven'a, blogoslo'v'in'a, blagoslo'venstvo, pro'syty blagoslo'ven'e v'id r'idn'i, blagoslo'vyty vi'nok, p'roshcha, p'roshchen'a, da'vaty p'roshchu, ka'zaty p'roshchu, pro'syty p'roshchu, ka'zaty 'kazan'e, ka'zaty p'ropovit', pok'lon i blagoslo'vin'a.

Aktsionational part of the wedding rite defines the role of nonverbal communication. The rite pilgrimage is theatrical performance (brides kneeling, this action is called in Bukovina vkl'a'katy, vpl'a'katy, pryk'l'aknuty, pry'pasty, pry'pasty na ko'lina) with obligatory wedding ,details" - bread, candles, icon - in the form of speech, that says usually older people and young people repeat it. Speech may have a different volume. Cultural term p'roshcha exists in wedding and funeral rites. The names of the rite action are represented in the form of the phrase: chy'taty p'roshchu, ka'zaty p'roshchu, pro'syty p'roshchu, hovo'ryty blahoslo'ven'a, ka'zaty 'kazan'e. It shows the role of verbal component (cliche) of ritual action. Rite terms ka'zaty 'kazan'e, pro'syty p'roshchu are built in form of tautology.

Name blahoslov'en'a is a compound word, tracing from Greek ${ }^{4}$, known since the thirteenth century. Parental blessing of brides after religious rite in Bukovinian dialects is entitled: kola'chi z vin'kom, klo'nyty kola'chi, klo'nyty do kola'chiu,

\footnotetext{
${ }^{1}$ Matushenko V. B. Suchasne vesillya v konteksti ukrayins'koyi obryadovoyi kul'tury [Modern Wedding Ritual in the Context of Ukrainian Rite Culture], K.: Stylos, 2009, P. 7.

${ }^{2}$ Guyvanyuk N. V. "Leksyka vesil'nogo obryadu“ [Vocabulary of Wedding Ceremony in the "Dictionary of Bukovinian Dialects"], Slovnyk bukovyns'kyh govirok, Kirovograd: RVV KDPU im. V. Vynnychenka, 2008, Vyp.75(1), P. 255.

${ }^{3}$ Slovnyk ukrayins'koyi movy [Dictionary of Ukrainian Language]. K.: Nauk. dumka, 1970-1980, Vol. III, P. 434.
} 
klo'nyty na 'golovu kola'chi, 'byty try ra'zy kola'chem po golo'vi, k'lan 'atysa, k'lan 'an'a.

In wedding rite nonverbal pantomime performance, verbalized by verb „to bend" klo'nyty „something stoop down”, becomes a symbol of blessing, ,consent to anything, permit someone to something", from it term klo'nyty kola'chi is derived. The specificity of the parental blessing that accompanies is verbal component. Some researchers have suggested that the earliest form of fixing the marriage was a father's blessing of the brides with bread and salt.

Wedding ceremony is based on church tradition, the wedding is important rite action „church marriage ceremony" that shows linguistic units: v'inchatysy, vin'chetysy, zvin'chetysy, zvin'chatysa, vinchen'ye, shl'up, sl'ub, i'ty do s'l'ubu, b'raty sl'up, i'ty b'raty shl'up, da'vaty shl'up.

The word „marriage” shl' $u b$ with the meaning ,marriage, wedding" has phonetic variants ${ }^{5}:$ shl'up, sl'ub, it is associated with Polish ślub ,promise marriage" that comes from ślubić “ to swear", but reduced to ljubiti ${ }^{6}$, to form the phrases: $i^{\prime} t y$ do s'l'ubu, b'raty sl'ub, i'ty b'raty shl'ub.

V. Prokopenko said that the value ,contract” of the word $s l^{\prime} u b$ is recorded in the Russki charters of fifteenth century. During the Moldavian principality this name often was used in official documents as ,,oath"7.

Names that denote ,civil marriage registration” are 'pysan'a, py'satysu(sa), spy'satysy, 'zapys, i'ty do 'zapysu, ros'pysuvatysy, they are motivated with the verb „to write" py'saty ,to play graphically details”.

Wedding event provides a spending time with fun. „Names of wedding entertainment" are represented by words: bal'u'vatysy, po'buty, na'butysy, na'butky, na'butok, zabau'l'etysy, za'bava, 'gul'ky, saban'tui.

Media pressure (radio, television) contributed input to the lexical system of Bukovinian dialects the word ,fun”, originally saban'tui, is a holiday that means the end of spring field work, through Russian, borrowed from the Tartar and Bashkir languages ${ }^{8}$.

Meaning „dance” in Bukovinian dialects is a linguistic unit of dantsu'vaty, tants'u'vaty, hu'l'aty, nahu'l'atysy, 'fayno t'ropnuty no'hou, pl'a'saty.

Words dantsu'vaty, 'danets are come from Bulgarian ,folk wedding dance", borrowed from Moldavian language ${ }^{9}$. In dialects of Khotyn district - pl'a'saty is associated with Old Slavonic plesati ,to jump, to rejoice" 10 .

Joint wedding meal is one of the most important rite, which reaches depths of ancient, when consume food was a sign of friendly attitude, and satisfying one of the most important needs of human existence. It plays a big role in the wedding event. Words ,eating” represent linguistic units: pryi'maty, k'lasty za st'iu, pryi'matysy, pryhosh'chaty l'u'dyi, pohost'u'vatysy, b'raty za stil, k'lasty za stil, zai'ty za stil, pochy'naty stil, pry'lahodyty sto'ly, narykhtu'vaty stil, za'vodyty sto'ly na ve'cher'u, zahosh'chatysy, pryhosh'chaty, vhosh'chatysy, chastu'vaty, chistu'vaty, potrakhtu'vatysa.

Bukovinian dialect actively functions with such word as pryi'maty (sy), that means ,to treat". In the Dictionary of Ukrainian Language among 18 values this meaning is not registered ${ }^{11}$

The idea of eating implements word „table” stil, which exists in phonetic variants s'kiu, s'tiu, skil and forms the irreducible expressions b'raty za stil, k'lasty za stil, zai'ty za stil, pochy'naty stil, naryhtu'vatu stil, pry'lahodyty sto'ly.

The meaning "to take a meal" recreates verbs which are motivated with word „guests" 'gosti: zahosh'chatysy (sa) pryhosh'chaty, vhosh'chatysy.

We separate thematic group ,names which denote an invitation to a meal": prypro'shaty, p'leskaty 'host'am, p'leskaty $u$ do'loni, vyhra'vaty do s'tolu, vyhra'vaty do 'portsiyi, napy'vatysy do 'hostey, hu'l'aty s 'portsiyeu, 'pyty do 'hostyi, pry'nuka.

For moral guidance of Bukovinians to eat in public is shame, guests must be asked to the consumption of food, in the nineteenth century this process was called pry'nuka. In Bukovinian wedding of the twentieth century mission of ,asking to the consumption of food" pryp'roshuvaty was pinned on special persons who were called s'vashky. These people walked between the rows of tables and applauded to guests: p'leskaly 'host'am, p'leskaly $v$ do'loni. The name reflects the reference situation which becomes portable symbolic meaning. The word ,to applaud" p'leskaty is etymologically akin to ,to hop" $p l^{\prime} a$ 'saty $^{12}$. Musicians walked between the rode of tables and encouraged guests to fun, hence came next expressions: vyhra'vaty do s'tolu, vyhra'vaty do 'portsiyi, vyhra'vaty do 'gostei. In the village Livyntsi of Kelmenetskyi district this rite evolved as follows: several times during the wedding guests stand up, sing and move to the music. This action is called hu'l'atys 'portsiyev.

Given the pragmatic foundation of wedding event, one of the most important rite of wedding stage is making the presents to the brides. The group ,names which denote presents" represents three nominative series. First is ,making presents for a family", second - ,to making presents for a family of brides by opposite side", third is ,to making presents for a brides".

At the wedding guests first visit was accompanied by gifts of the owners (many dialects name was not preserved) hha'z'ayin nu'se hlib / a 'zhinka nu'se 'kurku a'bo 'mysku mu'ky // tse ny $v^{\prime} k$ hodylo u chas'tovan'a //. To show how guests make presents at first in Bukovinian dialect exist such linguistic units: prykho'dyty $s$ pry'nosom, poda'vaty units: prykho'dyty $s$ pry'nosom, poda'vaty chest', pry'nesty chest': 'hoski poda'yut ches 'k'// kot'ri sta'ri / to da'yut 'tatovy $i$ 'mam"i //. Ceremonial term pry'nos is well known in all districts of Ukraine ${ }^{13}$.

Terms poda'vaty ches't', pry'nesty ches't' are proving semantic development of ,cpecific" and ,abstract” in popular speech. „Honor” ches't' is ,,set the highest moral principles, that

\footnotetext{
${ }^{5}$ Slovnyk ukrayins'koyi movy [Dictionary of Ukrainian Language], K.: Nauk. dumka, 1970-1980, Vol. XI, P. 491.

${ }^{6}$ Etymologichnyi slovnyk ukrayins'koyi movy [Etymological Dictionary of Ukrainian Language], K. : Nauk. dumka, 1982 - 2012 , Vol. VI, P. 441.

${ }^{7}$ Prokopenko V. A. "Leksyka vesil'nogo obryadu v bukovyns'kyh govorah" [Vocabulary of Wedding Ceremony in Bukovina Dialects], Tezy dopovidei XX naukovoyi sesiyi. Sekciya filolog.nauk. Chernivtsi, 1964, P. 43.

${ }^{8}$ Etymologichnyi slovnyk ukrayins'koyi movy [Etymological Dictionary of Ukrainian Language], K. : Nauk. dumka, 2012, Vol. V, P. 159.

${ }^{9}$ Ibid., Vol. II, P. 11.

${ }^{10}$ Ibid., Vol. IV, P. 463.

${ }^{11}$ Slovnyk ukrayins'koyi movy [Dictionary of Ukrainian Language], K.: Nauk. dumka, 1970 - 1980, Vol. VII, P. 623.

${ }^{12}$ Etymologichnyi slovnyk ukrayins'koyi movy [Etymological Dictionary of Ukrainian Language], K. : Nauk. dumka, $1982-2012$, Vol. IV, P. 463.

${ }^{13}$ Kayndl' R.F. Guculy: yih zhyttya, zvychayi ta narodni perekazy [Hutsuls: Their Life, Customs and Folk Retellings], Chernivtsi: Molodyi bukovynec', 2000, P. 25. 
guided people in their social and personal behavior", comes from the Polish $\check{c} s t$, associated with $\check{c} s t i$, čisti ,to read, count, honor".

In the twentieth century at the Bukovinian wedding relatives of brides are exchanged with gifts. Names correspond to the scheme ,to give present + noun denoting affinity in Accusative case: daru'vaty 'mamu, daru'vaty 'babu, daru'vaty seyst'ru (obda'rovuvaty 'mamu), daru'vaty 'khustku + daru' vatysy: za'vod'a do 'khaty / da'ruyuts:y //to'dy molo'dyi da'ruye tsyh / 'tata $i$ 'mamu molo'doyil/ ti da'ruyut molo'doho//. These terms are interpreted as transformed former ransom for the bride. Thus, R.F. Kayndl' mentions that „bride never receives a gift from the bride or her family”14

Rite action of making presents for a brides in North Bukovina has different names: 'pyty do molo'dyh, pro'piy, 'kydaty v pro'piy, 'kydaty v 'chashku, vy'taty, da'vaty na 'fustku, zby'raty 'chashku, perepy'vaty molo'du, vy'tan'e, 'pounytsa, chastu'vaty, pryi'maty da'ry, da'ruvaty molo'dyh, daru'vaty da'ry, sky'daty da'ry, sta'vaty do 'chesti, da'vaty na po'chesnu, gratyl'u'vaty, hratul'u'vaty, chas'tovan'a, chis'tovan'e, chastu'van'a, vykly'katy do koro'vayu i po'chesnoho.

Remains of former archetype of sale system remained names which motivated by word „to buy" kupu'vaty: sku'povuvaty molo'du, sku'povuvaty dru'zhok, 'vykupyty dereu'tse, 'vykup bat'kiu. General concept of these language units is word skup, registered in dialect of village Chornoguzy Vyzhnytsya district: 'pisl'a 'pounyts 'i zachy'nayesy skup.

The names of bride's redemption are denoted by such linguistic units: kupu'vaty ('vikupyty) molo'du, pla'tyty 'vykup, da'vaty 'vykup, 'vykup, 'vikup, p'rodazh molo'doyi, b'raty za kho'roshu, moho'rych, k'lasty blo'kadu, k'lasty stiu, viku'povuvaty ('vikupyty) b'ramu, vadro've, vahro've, ro'byty ro'hatku, zakla'daty ko'lodamy do'rohu, chipo've.

Redemption of bride is usually relied on brother or sister of the bride or her friends. In Nepolokivtsi dialect, Kitsmansky district, ransom for bride is called b'raty $z a$ kho'roshu. Perhaps local cultural term arose as a result of the reduction of phrase b'raty 'vykup za kho'roshu molo'du.

Foreclosures on dialect of Davydivka, Storozhynetsky district, is called k'lasty blo'kadu, national consciousness transfered the military terminology to the marriage one, the motives of ,military attack” is characteristic of marriage ceremony in general and in particular for wedding stage pe'reim. In dialect of Chornohuzy, Vyzhnytsya district, this rite has the name k'lastu s'tiu, s'tiu. The nomination motivates name of the object involved in the action. In some dialects, especially if the bride is from another village, ransom of bride has name vyku'povuvaty b'ramu, word ,gate" b'rama implements the archetype of sacred space.

There is a rite Bukovinian dialects term vadro've: vadro've: druzh'by molo'doyi s'toyut pid yi'yi vorit'my/ shob u'z'aty $z$ molo'doho 'vikup// vadro'vel/. Ceremonial vadro've is term, associated with the Romanian word vặdặrit „fee for crossing" ${ }^{\prime 2}$. People's minds transfered socio-economic terms to the marriage rites. Word vadro've exists in Bukovinian dialect in the form of adjective such as podush'ne, chipo've

In the sense of redemption we may use the word moho'rych, because usually the ransom is paid with alcoholic beverages: 'kolo vo'rit ye'ho st'rily 'nashi / z 'vulytsi parup'ky $i$ t'rebuvaly moho'rych / za to sho by're me'ne/l, compare with chipo've ,purchase of bride with alcoholic beverages"16.

The form of entertainment has rite of redemption of friends of the bride: kupu'vaty dru'zhok, sku'povuvaty dru'zhok, vyku'povuvaty dru'zhok.

In wedding ceremonies of hutsuls of Bukovina there is rite "to buy the wedding tree" 'vykupyty dereu'tse. If one of bride's friend don't keep the tree, he should buy it.

In dialect of Banyliv, Vyzhnytsya district, it is recorded the name of rite 'vykup bat'k'iu. The parents of bride, if the child who marries is last, were taken in a wheelbarrow to the edge of the village and demanded ransom.

One of the central wedding rite is a covering of a bride . The names of this ritual are: pokry'vaty molo'du, pokry'van'a molo'doyi, pidkry'vaty molo'du, pokry'vaty turpa'nom, zavy'vaty molo'du, zavy'vaty $u$ 'fustku, zavy'vaty $u$ tur'pan, zavy'vaty $u$ rush'nyk, rozby'raty molo'du, sky'daty vi'nok, zau'yazuvaty (za'uyezuvaty) 'fustku, pokry'vaty 'fustkou, sky'daty fa'tu $i$ uby'raty 'fustku, peyreyby'raty molo'du, sky'daty vi'nok $i$ na 'holovu k'lasty pokry'valo, pou'yazuvaty hus'tynu, zau'yazuvaty molo'du u pla'tok, pok'riul'a molo'dyh, rozby'raty molo'du.

The rite of bride's covering in Novoselytsya dialects is called rozby'raty molo'du. This ritual is the complex of two actions - to remove wreath and to cover the head.

Conclusions. The semantic and functional analysis of vocabulary to describe the actual wedding rite, is representing the spiritual culture of Bukovina, shows only linguistic and imaginative world of the Ukrainian nation. Lexical representation of the wedding rite is caused by various of forms and internal nominations. Several nominations of wedding rite illustrate the relics of previous philosophical systems of Bukovinians.

Руснак Ю. Власне весільні обрядотерміни у буковинських говірках. В статті проаналізовано власне весільну обрядову термінологію у буковинських говірках. Дослідження відповідає етнолінгвістичному аспекту мовознавства, оскільки лексика родинної обрядовості у говірках становить шар лексем з так званим „культурним компонентом”, тобто в них віддзеркалено реалії культури певного народу. Одиницею опису номінацій власне весільного етапу обрано номінативний ряд - сукупніть номінації на позначення одного денотата.

Семантико-функціональний аналіз лексики на позначення власне весільних обрядів, що репрезентують духовну культуру буковинців, засвідчує єдиний мовно-образний світ української нації. Лексичні репрезентанти на позначення власне весільних обрядотермінів спричинені різними внутрішніми формами номінацій. Низка номінацій власне весільних обрядодій ілюструє релікти попередніх світоглядних систем буковинців.

Ключові слова: весільний обряд, буковинські говірки, номінатвний ряд, духовна культура, номінація.

Руснак Юлія - кандидат філологічних наук, старший викладач кафедри суспільних наук та українознавства ВДНЗ Украйни «Буковинський державний медичний університет». Після захисту кандидатської дисертачії ,Лексика родинних обрядів у буковинському діалекті" за спеиіальністю 10.02.01. - українська мова автор продовжує дослідження у галузі діалектології, етнолінгвістики, викладання украӥнської мови як іноземної. У доробку науковия є 25 публікації.

Rusnak Yulia - candidate of philological sciences, senior teacher of the Department of Social Sciences and Ukrainian Studies of Higher State Educational Establishment of Ukraine «Bukovinian State Medical University». After defending her dissertation ,The vocabulary of family rituals in Bucovina dialect” in the specialty 10.02.01. - Ukrainian language keeps on researching in the field of dialectology, ethnolinguistics, teaching Ukrainian as a foreign language. In the works of the scientist are 25 publications.

\section{Received: 10-01-2017}

Advance Access Published: April, 2017

(C) Y. Rusnak, 2017

\footnotetext{
${ }^{14}$ Rumuns'ko-rosiys'kyi slovnyk [Romanian-Russian Dictionary], Bacău, 2008, P. 745

${ }^{15}$ Slovnyk bukovyns'kyh govirok [Dictionary of Bukovinian Dialects], Chernivtsi: Ruta, 2005, P. 646.
} 